BIOMEDICAL AND BIOSOCIAL ANTHROPOLOGY
Official Journal of the International Academy
of Integrative Anthropology
journal homepage: http://bba-journal.com

\title{
Comparison of quality of life in postoperative patients with cholecystolithiasis and choledocholithiasis. The difference between open and laparoscopic treatment
}

\section{Halei M. M. ${ }^{1,2}$, Dziubanovskyi I. Ya. ${ }^{2}$, Marchuk I. P. ${ }^{1}$}

${ }^{1}$ Volyn Regional Clinical Hospital, Volyn, Ukraine

2I. Ya. Horbachevsky Ternopil State Medical University, Ternopil, Ukraine

\section{ARTICLE INFO}

Received: 21 June, 2019

Accepted: 25 July, 2019

UDC: $617.551-009.7$

\section{CORRESPONDING AUTHOR}

e-mail: galej_kamy@tdmu.edu.ua Halei M. M.

\begin{abstract}
Gallstone disease is quite common in the adult population and can quickly cause lifethreatening conditions that require extensive surgical treatment. In recent years, the assessment of quality of life is becoming increasingly important in world medicine as an indicator of the general condition of the patient and the effectiveness of treatment and rehabilitation measures. The aim of this work - to collect and calculate indicators of quality of life in postoperative patients with gallstones of gall bladder and common bile duct; to compare data from patients with open and laparoscopic treatment; to determine the advantages of the treatment methods. For rating quality of life 36-Item Short-Form Health Status (SF-36) was used. The statistic was collected using retrospective analysis of worked out data in laparoscopic surgery unit in Volynian regional state hospital during 2016-2019 (191 patients). Patients of group I (113 patients) underwent laparoscopic treatment, patients of group II used open surgical treatment (78 people). Statistical processing was performed using the program "Statistica 6.0" (Statsoft Inc., USA). In group I pain level in first two hours was significantly lower than in group II (6.2 vs 8.4 in 10 point scale), in addition, pain relief became faster reaching low pain level of abdomen in 2.48 days. In group II pain level was higher (8.4 points) and pain relief was reached in 5.11 days. Oral nutrition and verticalisation were renewed in 14.7 \pm 3.1 hours in group I, and in $22.9 \pm 5,5$ hours in group II and $6.1 \pm 1,9$ hours in group I vs $19.7 \pm 3,3$ hours in group II. Also, according the results SF-36, quality of life indicators indicate faster recovery in the group of laparoscopic treatment compared to the group with the classic version of the operation. The physical functioning and physical performance of the role differed significantly in favor of laparoscopic treatment throughout the follow-up period. Pain indicators in the first group were satisfactory after 1 month of rehabilitation, while in the second group such indicators were achieved only after 6 months - 91/94/94 vs. 74/89/94. Although psychological well-being differed between 1 and 3 months, in favor of minimally invasive treatment, after 6 months the data were comparable in both groups.
\end{abstract}

Keywords: gallstone disease, laparoscopy, simultaneous, SF-36 questionnaire.

\section{Introduction}

In recent years, the assessment of quality of life is becoming increasingly important in world medical practice as an indicator of the general condition of the patient, the effectiveness of treatment and rehabilitation measures, and is used as a prognostic criterion for disease resolution [3].

As early as 1948, the WHO defined health not only as the absence of disease, but also as the presence of physical, psychological and social well-being [18]. Since then, medical practice has increasingly begun to pay attention to quality of life.

Gallstone disease is quite common in the adult population of Western countries, due to the specifics of lifestyle, nutrition [18]. The most common manifestation is cholecystolithiasis. According to various data, it affects $30 \%$ of the adult population [18]. Choledocholithiasis is also a frequent complication of cholecystolithiasis [2]. Choledocholithiasis itself can cause serious complications, such as biliary pancreatitis, gallbladder, 
mechanical jaundice, which is quite life-threatening [16]. Disruption of the bile duct can quickly cause life-threatening conditions that will require extensive surgical treatment [8]. One of the most formidable complications is acute pancreatitis, which in $35 \%$ of cases is caused by a violation of the passage of bile $[11,17]$. That is why the study of surgical treatment of this pathology is relevant.

This article presents a comparative assessment of the simultaneous treatment of gallstone disease (GD), namely open cholecystectomy with choledocholithotomy and laparoscopic cholecystectomy with laparoscopic choledocholithotomy.

The purpose of the work - to determine the quality of life in postoperative patients with gallstones and common bile duct in 1, 3 and 6 months after surgery; to compare time indicators of verticalization, reduction of a pain syndrome, restoration of oral food, time of hospitalization at patients; identify the benefits of the methods.

\section{Materials and methods}

Strategies were evaluated by determining and comparing the postoperative period in patients who underwent surgical treatment, namely by assessing the time of hospitalization, time of verticalization and recovery of oral nutrition as important indicators for assessing the postoperative condition of patients [10] who underwent laparoscopic and open surgery, and also levels of quality of life. The main tool for numerical determination of quality of life is a questionnaire. In our work, we used the SF-36 questionnaire, as we believe it is effective for assessing the quality of life of patients after surgery [7], with its help you can quickly and accurately determine the quality of life and obtain this indicator through numerical expression. Also, the questionnaire is easy to understand and interpret for patients themselves, which is also important enough to form a true statistical base. SF-36 has 36 questions that form 8 scales (PF - physical component, RP - the ability to physically perform a social role, BP - pain, GH - general condition, VT - vital activity, SF - social functioning, RE - the ability to emotionally perform social role, $\mathrm{MH}$ - mental health). The higher the score on the SF36 questionnaire scale, the better the quality of life. Testing took place after 1,3 and 6 months with prior voluntary consent. Statistical analysis included descriptive statistics and assessment of differences. The obtained data were checked, processed and analyzed using a computer program. Statistical processing was performed using the program "Statistica 6.0" (Statsoft Inc., USA).

To develop the statistical base, we developed case histories of patients operated in the department of invasive methods of diagnosis and treatment of Volyn Regional Clinical Hospital (Volyn Regional Clinical Hospital) in 20162019. Namely: 113 case histories of patients (36 men with an average age of 58.44 years and 77 women with a mean age of 52.63 years) who underwent laparoscopic simultaneous (single) cholecystectomy and choledocholithotomy and who made up group I and 78 case histories of patients (27 men with a mean age of 55.91 years and 51 women with a mean age of 58.22 years) who underwent open simultaneous (single) cholecystectomy and choledocholithotomy, which formed the group II. ERAS (Enhanced Recovery After Surgery) principles were used in both groups.

The latter point to the critical importance of rapid recovery of oral nutrition and self-verticalization of postoperative patients, to reduce the level of postoperative complications, as well as to improve the quality of care [10].

In both groups the number of concomitant pathologies was comparable, but did not differ from that expected in surgical patients [5], on average - 2 (most often it is gastroesophageal reflux disease - 38 people (19.9\%), erosive gastritis - 52 people (27.2\%), hypertension - 101 people $(52.9 \%))$.

\section{Results}

The analysis of the results of the obtained data showed that the pain syndrome in patients of group I was present only in the first 2 days (average 2.48 days), and on the second day after surgery it was observed only during active movement. In the first 2 hours, the pain, assessed by patients on points from 1 to 10 , averaged 6.2 points, after 48 hours -2.8 . In group II, the pain lasted from 4 to 7 days (average 5.11 days), in the first two hours the pain rating was 8.4 , after 48 hours -5.3 points. Independent getting up of patients in the first group was possible in $6.1 \pm 1.9$ hours, in the second group - in $19.7 \pm 3.3$ hours after the operation is completed.

Oral nutrition was resumed in patients of the first group after $14.7 \pm 3.1$ hours, in the second group - after $22.9 \pm 5.5$ hours after the operation is completed. The average quality of life of the operated patients is shown in table 1 and figures 1 and 2 for the group of laparoscopic treatment of housing and communal services and open surgical treatment, respectively.

Table 1. Quality of life (SF-36) of operated patients with open and laparoscopic treatment.

\begin{tabular}{|c|c|c|c|c|c|c|}
\hline \multicolumn{7}{|c|}{ Quality of life } \\
\hline \multirow{3}{*}{ Indicators } & \multicolumn{3}{|c|}{ Group 1 } & \multicolumn{3}{c|}{ Group 2 } \\
\cline { 2 - 7 } & $\begin{array}{c}1 \\
\text { months }\end{array}$ & $\begin{array}{c}3 \\
\text { months }\end{array}$ & $\begin{array}{c}6 \\
\text { months }\end{array}$ & $\begin{array}{c}1 \\
\text { months }\end{array}$ & $\begin{array}{c}3 \\
\text { months }\end{array}$ & $\begin{array}{c}6 \\
\text { months }\end{array}$ \\
\hline PF & 68 & 72 & 77 & 61 & 64 & 69 \\
\hline RPF & 84 & 85 & 88 & 71 & 75 & 75 \\
\hline BP & 91 & 94 & 94 & 74 & 89 & 94 \\
\hline GH & 73 & 76 & 78 & 67 & 72 & 75 \\
\hline VT & 73 & 76 & 84 & 63 & 74 & 84 \\
\hline SF & 86 & 88 & 89 & 84 & 87 & 88 \\
\hline REF & 79 & 81 & 83 & 79 & 80 & 81 \\
\hline MH & 88 & 90 & 90 & 81 & 85 & 90 \\
\hline
\end{tabular}




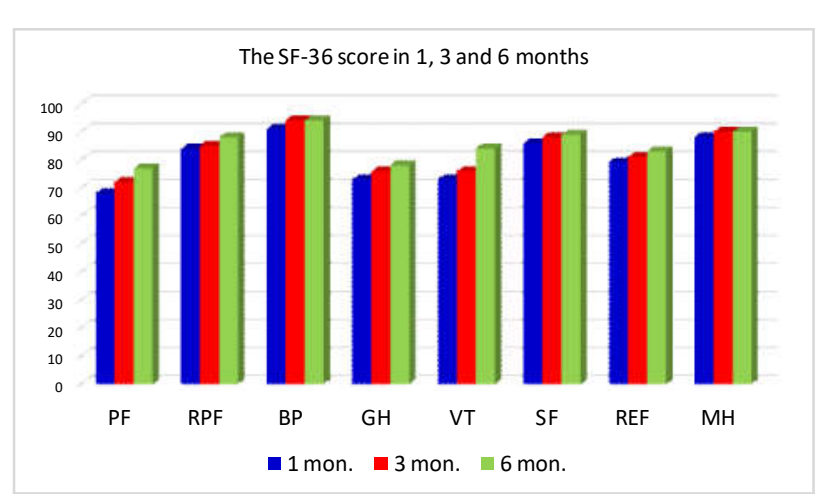

Fig. 1. Assessment of quality of life in postoperative patients in the group of laparoscopic cholecystectomy and choledocholithotomy. Notes: hereinafter, y-axis - points from 0 to $100, P F$ - physical component, RP - the ability to physically perform a social role, BP pain, GH - general condition, VT - vital activity, SF - social functioning, $\mathrm{RE}$ - opportunity emotional performance of a social role, $\mathrm{MH}$ mental health.

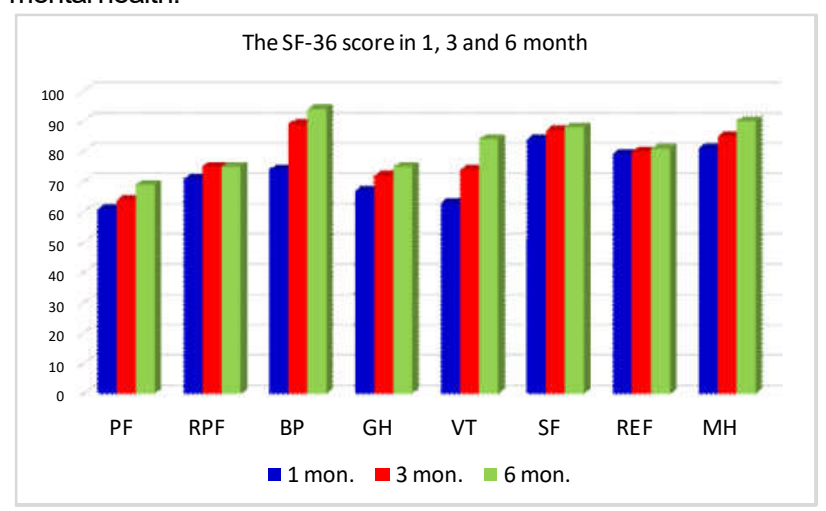

Fig. 2. Assessment of quality of life in postoperative patients in the group of open cholecystectomy and choledocholithotomy.

\section{Discussion}

The World Community for Enhanced Recovery After Surgery (ERAS) recommends in all its recommendations to prefer minimally invasive interventions, especially in general surgery, where laparoscopy has developed the most [14]. Endocrine-metabolic stress resulting from tissue damage slows recovery [15]. The greater the damage, the longer the operation, the more interleukin- 6 is released, the more stress develops in response [5]. A larger incision causes more pain and prevents early verticalization, which is a very important factor in the patient's recovery, return to normal functioning and reduction of postoperative complications [12]. Also, the restoration of oral nutrition minimizes the effect of stress diabetes, which is a leading factor in the healing of surgical wounds, the development of infectious postoperative complications $[1,19]$. The results of the study suggest a more appropriate use of laparoscopic simultaneous techniques for the treatment of cholecystolithiasis in combination with choledocholithiasis. It is clear that to perform such operations, in comparison with the open method of treatment, it is necessary to provide the doctor with additional equipment, and the specialist must have the appropriate qualifications and surgical skills. But less trauma to the patient significantly affects the rehabilitation and postoperative period not only during hospitalization, but also 6 months after discharge [13], which is an important indicator of the effectiveness of the method [6]. The difference between the level of pain and the time during which the patient can eat and get out of bed, ie self-care, significantly affects not only the physical but also the psychological state of the patient. These indicators differ favorably in the group of laparoscopic treatment, compared with open. The use of minimally invasive methods is also recommended by the ERAS community as one of the main factors influencing the patient's recovery and recovery, hospital stay and economic feasibility.

After open surgery, rehabilitation of patients is slower than after laparoscopic, sometimes it is not possible to restore functional activity of the patient after six months of rehabilitation. Estimates of indicators such as pain or physical functioning differ significantly not only in the short term, but also in 6 months, although the difference becomes less critical over time. Although the pain component did not differ in both groups, the physical role and the physical component in the open surgery group recovered less. According to the SF-36 quality of life questionnaire, the data indicate not only better physical performance, but also a much better mental health status in patients who were treated minimally invasively. This is due to the absence of severe pain and exhaustion after major surgery, and the absence of a cosmetic defect contributes to a psychologically easier perception of small accesses over a large incision, as well as faster rehabilitation with recovery, which helps patients realize their recovery.

The technique of simultaneous laparoscopic interventions has many opportunities for development, because comorbidity in surgical patients is not uncommon. The most common combinations of surgical pathologies within the abdominal cavity are cholecystolithiasis and diaphragmatic esophageal hernia, cholecystolithiasis and inguinal hernia, cholecystolithiasis and liver tumors, cholecystolithiasis and kidney tumors [12]. Therefore, the implementation of simultaneous surgical treatment for these groups of patients is promising.

\section{Conclusions}

1. Rehabilitation of patients in the group of laparoscopic treatment is faster compared to the group of open surgical treatment: pain at rest disappears twice as fast (2.48 days, against 5.11 days, respectively); initial pain rates are lower $(6.2 / 10$ in the first two hours and $2.8 / 10$ in 48 hours against $8.4 / 10$ and $5.3 / 10$, respectively); verticalization after the operation is earlier ( $6.1 \pm 1.9$ hours, against $19.7 \pm 3.3$ hours, respectively); oral nutrition was restored faster after the operation (14.7 \pm 3.1 hours against $22.9 \pm 5.5$ hours, respectively). 
2. Quality of life indicators indicate faster recovery in the group of laparoscopic treatment compared to the group with the classic version of the operation. The physical functioning and physical performance of the role differed significantly in favor of laparoscopic treatment throughout the follow-up period - 68/72/77-84/85/88 vs. $61 / 64 / 69-71 /$ $75 / 75$. Pain indicators in the first group were satisfactory

\section{References}

[1] Bar-Or, D., Rael, L. T., Madayag, R. M., Banton, K. L., Tanner, A., Acuna, D. L., ... \& Mains, C. W. (2019). Stress Hyperglycemia in Critically III Patients: Insight Into Possible Molecular Pathways. Frontier Medicine, 6, 54. doi: 10.3389/fmed.2019.00054

[2] Bloom, A. A. (2019). What is the pathogenesis of acute Cholecystitis? Emedicine. Medscape / article - 171886. Retrieved from https://emedicine.medscape.com/article/ 171886-overview

[3] Hays, R., Bjorner, J. B., Revicki, D. A., Spritzer, K. L., \& Cella, D. (2009). Development of physical and mental health summary scores from the patient-reported outcomes measurement information system (PROMIS) global items. Quality of Life Research, 18(7), 873-880. doi: 10.1007/s11136-009-9496-9

[4] Heuman, D. M. (2019). Gallstones (Cholelithiasis). Medscape / article - 175667. Retrieved from https:// emedicine.medscape.com/article/175667-overview

[5] Hu, J., Feng, X., Valdearcos, M., Lutrin, D., Uchida, Y., Koliwad, S. K., \& Maze, M. (2018). Interleukin-6 is both necessary and sufficient to produce perioperative neurocognitive disorder in mice. British Journal of Anaesthesia, 120(3), 537e545. doi: 10.1016/j.bja.2017.11.096

[6] Ivanko, O., \& Kalina, R. (2012). Comparative assessment of the quality of life of patients after open and laparoscopic appendectomy. Hospital surgery, 3, 26-29. Retrieved from https://webcache.googleusercontent.com/ search?q=cache:un6H1SR2gqUJ:https://ojs.tdmu.edu.ua/ index.php/surgery/article/download/1961/1866/ $+\& \mathrm{~cd}=1 \& \mathrm{hl}=\mathrm{ru} \& \mathrm{ct}=\mathrm{clnk} \& \mathrm{gl}=\mathrm{ua}$

[7] Jenkinson, C., Layte, R., Jenkinson, D., Lawrence, K., Petersen, S., Paice, C., \& Stradling, J. (1997). A shorter form health survey: can the SF-12 replicate results from the SF-36 in longitudinal studies? Journal of Public Health Medicine, 19(2), 179-186. doi: 10.1093/oxfordjournals.pubmed.a024606

[8] Machado, F. H. F., Castro, F. H. F., Babadopulos, R. F. A. L., Rocha, H. A. L., Rocha, J. L. C., \& Moraes, F. M. O. (Feb 14 2019). Ursodeoxycholic acid in the prevention of gallstones in patients subjected to Roux-en-Y gastric bypass1. Acta Cir. Bras., 34(1), e20190010000009. doi: 10.1590/s0102865020190010000009

[9] Mehta, H. B., Dimou, F., Adhikari, D., Tamirisa, N. P., Sieloff, E., Williams, T. P., ... \& Riall, T. S. (2016). Comparison of Comorbidity Scores in Predicting Surgical Outcomes. Med. Care, 54(2), 180-187. doi: 10.1097/MLR.0000000000000465

[10] Melloul, E., H?bner, M., Scott, M., Snowden, C., Prentis, J., Dejong, C. H. C., ... \& Demartines, N. (2016). Guidelines for Perioperative Care for Liver Surgery: Recommendations. World after 1 month of rehabilitation, while in the second group such indicators were achieved only after 6 months - 91/94/ 94 vs. 74/89/94. Although psychological well-being differed between 1 and 3 months, in favor of minimally invasive treatment, after 6 months the data were comparable in both groups.

Journal of Surgery, 40(10), 2425-2440. doi: 10.1007/s00268016-3700-1

[11] Mikolasevic, I., Orlic, L., Poropat, G., Jakopcic, I., Stimac, D., Klanac, A., ... \& Milic, S. (2017). Nonalcoholic fatty liver and the severity of acute pancreatitis. European Journal of Internal Medicine, 38, 73-8. doi: 10.1016/j.ejim.2016.10.019

[12] Milovanovic, A., Grujicic, D., Bogosavljevic, V., Jokovic, M., Mujovic, N., \& Markovic, I. P. (2017). Efficacy of Early Rehabilitation After Surgical Repair of Acute Aneurysmal Subarachnoid Hemorrhage: Outcomes After Verticalization on Days 2-5 Versus Day 12 Post-Bleeding. Turk Neurosurg., 27(6), 867-873. doi: 10.5137/1019-5149.JTN.17711-16.1

[13] Novik, A. A., \& lonova, T. I. (2007). Guide to the study of the quality of life in medicine. Moscow: Olma groups.

[14] Scott, M. J., Baldini, G., Fearon, K.C.H., Feldheiser, A., Feldman, L. S., Gan, T. J., ... \& Carli, F. (2015). Enhanced Recovery After Surgery (ERAS) for gastrointestinal surgery, part 1 pathophysiological considerations. Acta anesthesiology Scandinavica, 59(10), 1212-1231. doi: 10.1111/aas.12601

[15] Smith, R., Kee, A., \& Barrat, S. (2008) Depth of anesthesia with desflu-rane does not influence the endocrine-methabolic response to pelvic surgery. Acta Anaesthesiology Scandinavica, 52(1), 99-105. doi: 10.1111/j.13996576.2007.01470.x

[16] Tornqvist, B., Waage, A., Zheng, Z., Ye, W., \& Nilsson, M. (2016). Severity of acute cholecystitis and risk of iatrogenic bile duct injury during cholecystectomy, a population-based case-control study. World Journal of Surgery, 40(5), 1060-7. doi: $10.1007 / \mathrm{s} 00268-015-3365-1$

[17] Vege, S. S., Ziring, B., Jain, R., \& Moayyedi, P. (2015). American Gastroenterological Association institute guideline on the diagnosis and management of asymptomatic neoplastic pancreatic cysts. Gastroenterology, 148(4), 819-22; quiz 123. doi: 10.1053/j.gastro.2015.01.015

[18] World Health Organization. (1948). WHO Definition of Health. Preamble to the Constitution of the World Health Organization as adopted by the International Health Conference, New York, 19-22 June, 1946; Official Records of the World Health Organization, 2, 100.

[19] Zawn Villines. (2019). How does diabetes affect wound healing? Medical news today. Wound Source. https:// www.woundsource.com/blog/how-diabetes-impactswound-healing\#: :text=High\%20blood $\% 20$ glucose $\% 2$ 0causes $\% 20$ stiffening,complications $\% 20$ in $\% 20$ diabetes $\%$ 20wound\%20healing

\section{ПОРІВНЯЛЬНА ОЦІНКА ЯКОСТІ ЖИТТЯ У ПІСЛЯОПЕРАЦІЙНИХ ХВОРИХ З КАЛЬКУЛЬОЗНИМ ХОЛЕЦИСТИТОМ ТА} ХОЛЕДОХОЛІТІАЗОМ. РІЗНИЦЯ МІЖ ВІДКРИТИМ ТА ЛАПАРОСКОПІЧНИМ ЛІКУВАННЯМ

Галей М. М., Дзюбановський І. Я., Марчук І. П.

Жовчнокам'яна хвороба є достатньо поширеною у дорослого населення та може швидко викликати стани, що загрожують життю і потребуватимуть об'ємного хірургічного лікування. В останні роки оцінка якості життя набуває все більщого значення у світовій медицині як показник загального стану пацієнта та ефективності лікувальних і реабілітаційних заходів. Мета роботи - зібрати та обчислити показники якості життя у післяопераційних пацієнтів із конкрементами жовчного 
міхура та холедоха; порівняти дані пацієнтів з відкритим та лапароскопічним лікуванням; визначити переваги способів лікування. Для оцінки якості життя використали опитувальник 36-Item Short-Form Health Status (SF-36). Cmaтистичні дані отримані шляхом ретроспективного аналізу даних, напрацьованих в умовах відділення лапароскопічної хірургії Волинської обласної державної лікарні в 2016-2019рр. (191 пацієнт). Хворим I групи (113 осіб) застосовано лапароскопічне лікування, хворим II групи застосовано відкрите операційне лікування (78 осіб). Статистичну обробку виконували за допомогою програми "Statistica 6.0" (Statsoft Inc., USA). Встановлено, що у хворих першої групи первинний рівень болю $(6,2$ проти 8,4 за 10 бальною шкалою) в перші дві години після операції був нижчим і пропадав раніше, досягаючи значень низької болючості черевної стінки, тільки при напрузі в середньому за 2,48 доби, тоді як у другій групі первинний рівень болю був вищим (8,4 бали) і час зниження болю (5,11 дня) був вищим. Самостійне пероральне харчування та вертикалізація хворих також були

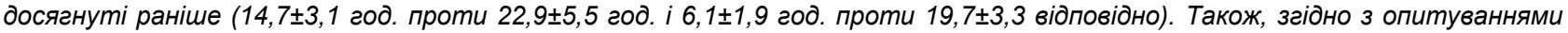
хворих за SF-36, показники якості життя вказують на швидше відновлення у групі лапароскопічного лікування порівняно 3 групою з класичним варіантом операції. Фізичне функціонування та фрізичне виконання ролі відрізнялись суттєво на користь лапароскопічного лікування протягом усього періоду нагляду. Показники болю у першій групі були задовільними уже через 1 місяць реабілітації, тоді як у другій групі такі показники досягались лише через 6 місяців - 91/94/94 проти 74/89/94. Психологічне самопочуття хоч мало різницю у термінах 1 та 3 місяці, на користь малоінвазивного лікування, через 6 місяців дані були зіставні у обох групах.

Ключові слова: жовчнокам'яна хвороба, лапароскопія, симультанний, опитувальник SF-36.

\section{СРАВНИТЕЛЬНАЯ ОЦЕНКА КАЧЕСТВА ЖИЗНИ У ПОСЛЕОПЕРАЦИОННЫХ БОЛЬНЫХ С КАЛЬКУЛЕЗНЫМ ХОЛЕЦИСТИТОМ И ХОЛЕДОХОЛИТИАЗОМ. РАЗНИЦА МЕЖДУ ОТКРЫТЫМ И ЛАПАРОСКОПИЧЕСКИМ ЛЕЧЕНИЕМ Галей Н. М., Дзюбановский И. Я., Марчук И. П.}

Желчнокаменная болезнь является достаточно распространенной у взрослого населения и может быстро вызвать состояния, угрожающие жизни и нуждающиеся в объёмном хирургическом лечении. В последние годы оценка качества жизни приобретает все большее значение в мировой медицине как показатель общего состояния пациента и эффективности лечебных и реабилитационных мероприятий. Цель работы - собрать и измерить показатели качества жизни у послеоперационных пациентов с конкрементами желчного пузыря и холедоха; сравнить данные пациентов с открытым и лапароскопическим лечением; определить преимущества методов лечения. Для оценки качества жизни использовали опросник 36-Item Short-Form Health Status (SF-36). Статистические данные получены путем ретроспективного анализа данных, наработанных в условиях отделения лапароскопической хирургии Волынской областной клинической больницы в 2016-2019 ге. (191 пациент). Больным I группы (113 человек) применено лапароскопическое лечение, больным II группы применено открытое операционное лечение (78 человек). Статистическую обработку выполняли с помощью программы "Statistica 6.0" (Statsoft Inc., USA). Установлено, что у больных первой группы первичный уровень боли (6,2 по 10-балльной шкале) в первые два часа после операции был ниже и пропадал раньше, достигая значений низкой болезненности брюшной стенки только при напряжении в среднем за 2,48 суток, тогда как во второй группе первичная болезненность была выше (8,4 балла) и время снижения боли (5,11 дня) было выше. Самостоятельное пероральное питание и вертикализация больных

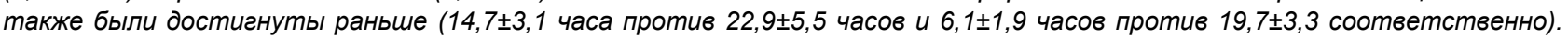
Также согласно опросу больных по SF-36, показатели качества жизни указывают на быстрое восстановление в группе лапароскопического лечения по сравнению с группой с классическим вариантом операции. Физическое фрункционирование и фризическое исполнение роли отличались существенно в пользу лапароскопического лечения в течение всего периода наблюдения. Показатели боли в первой группе были удовлетворительными уже через 1 месяи реабилитации, тогда как во второй группе такие показатели достигались только через 6 месяцев - 91/94/94 против 74/89/94. Психологическое самочувствие хоть и имело разницу в терминах 1 и 3 месяца, в пользу малоинвазивного лечения, через 6 месяцев данные были сопоставимы в обеих группах.

Ключевые слова: жёлчнокаменная болезнь, лапароскопия, симультанный, опросник SF-36. 